\title{
Furtive Temporalities in the Contemporary Visual Image: The Case Studies of Stan Douglas, Doug Aitken and Mark Lewis
}

\author{
Jesús Segura Cabañero ${ }^{1}$, Toni Simó Mulet $^{1}$ \\ ${ }^{1}$ Faculty of Fine Arts, University of Murcia, Murcia, Spain \\ Correspondence: Jesús Segura Cabañero, Faculty of Fine Arts, University of Murcia, Spain, Campus de Espinardo, \\ 30100 Murcia, Spain.
}

Received: October 23, 2015 Accepted: November 10, 2015 Online Published: November 20, 2015

doi:10.11114/smc.v3i2.1159 URL: http://dx.doi.org/10.11114/smc.v3i2.1159

\begin{abstract}
A large part of the recent artistic production is focuses on audiovisual works of art in which the idea of time and space-time interpretations induce the spectator's reflection. These artwork installations use the strategy of slowing down, speed, interruption or spatializing the rhythm and the sequence of the image in movement and question the perception of the spectator's everyday temporality and affect their visual experience. We explore the hegemonic chronologies through the artists and their production and reproduction of moving images that corresponds to the emergence of a range of critical and methodological proposals or model analysis of images that introduce multiple temporal levels. Such temporal multiplicity acquires an essential role in the global contemporary art scene, where different timelines from various contexts of the globe converge antagonistically in what we call "the modern world". Therefore, any attempt to write about this artwork needs to rethink the concept of time and assess both the temporal multiplicity (heterochrony) and investment of time and history (anachronism). This paper attempts to analyze the temporality, the collective imagination, history and memory, and moving image and its manipulation as a conceptual resource in the work of Stan Douglas, Doug Aitken and Mark Lewis.
\end{abstract}

Keywords: temporality, space, memory, perception, video, installation

\section{Introduction}

The present study has as a starting point the investigation of the concept of temporality in the work of different artists that incorporate the process of time as a core focus in their proposals. These image temporalities address the centrality of time as the subject in art, visual culture and the contemporary. Through several case studies, we try to explore the ways in which persistent alterations of temporality constitute modes of resistance to a conception of time and history. Transformations and convulsions of the image subject to various temporary architectures provide a meeting point with parallel investigations of contemporary artists who incorporate a larger, multidisciplinary project on temporary visual image.

This article explores temporal and analytical issues from the work of artists who have made temporality, one of the objects of analysis and intervention in their artistic production, such as the work of Stan Douglas, Doug Aitken and Mark Lewis. In the late 1990's a debate was introduced into the artistic discourse on the meaning and characterization of the contemporary, the new media and the techno-progress. The idea of conflicting temporalities, the media and obsolete objects began to be challenged by thinkers such as Giorgio Agamben and Michel Serres, where instabilities of chronology and the multiplicity of disjunctive times make up our idea of the present. These authors lucidly found in temporary disruptions of heterochrony, anachronism and polytemporality, a potential dialectics waiting to be unveiled to exceed the fixed idea about current and linear progressive discourse of time and events.

Firstly, in this paper, we focus on the authors and theories that have reflected in the emergence of modern time, testing the different points of view on which this text is based. With reference to the idea of spatial and temporal context of contemporary artists being discussed, a first work of art "Inconsolable Memories" by Stan Douglas is analyzed as a rewriting of memory, a recombination of historical narratives and collective memory in cinema. In the work of art "Interiors" by Doug Aitken, we explore hybridization and narrative discontinuity, exposing the surrounding and fragmentary narratives that reveal its geopolitical visual constructs. Finally, we discuss the piece "North Circular" by Mark Lewis and his emphasis on place, context and anachronism. These are the case studies for the development of an 
analysis of the reception of contemporary art based on the hybrid temporalities dissertation.

\section{Temporary Genealogies in Memory and Image: The Temporal Modernity}

In order to achieve a discourse to analyze convulsions and transformations of memory issues we have to specify contemporary artistic production in the last two decades. However, we are interested in those artistic productions that address social, political and economic issues from a perspective where these ideals do not proclaim themselves, they are not decreed, but are embedded in the production process. We are interested in the ways that the relationships with images are made, even thinking that these relationships are those that can release their ideological character. In short, those that develop representational issues that delves into a confrontation of disparate and global worlds to form concrete and local imaginary. Transcultural models gestate this operation where global parameters are implemented by local realities. Generating temporary architectures that require analysis to try to understand the symbolic adhesions inserted in this process, and that inevitably changed the concept of memory system crosses this. In this regard Andreas Huyssen says:

The globalization of memory also operates in two interrelated ways that illustrate what I would call the paradox of globalization (...) Is precisely the emergence of the Holocaust as a universal trope allowing the Holocaust memory to devote itself to specifically local, distant and different situations in historical terms in political terms of the original event in the transnational movement of discourses of memory. The Holocaust loses its quality index of the specific historical event and begins to function as a metaphor for other traumatic histories and its memory (2002, p. 4).

From this genealogy it is interesting to try this memorial thread often through an art that "thinks" the relationship of its own representational structure and generating knowledge about the world (Damisch, 1995), (Bal, 2001), (Van Alphen, 2009) to articulate a thought with images (Buck-Morss, 2005) that does not exclude works of art shaped as archives and repositories. Brought out as living organisms, conveying knowledge (Ricoeur, 1999), (Huyssen, 2002), (Didi-Huberman, 2005), (Guasch, 2011) to raise the otherness and consequently set other memories.

Mapping, marking and revealing the mobility of memory anchored in the construction of linear historical time of modernity and confronting it with memory formation arising in a system of heterochronic equivalences, or what Andreas Huyssen (2002) has called "The memory turn", allows us to speak of a memory and a hybrid and polyhedral time. These global reports based on time are configured by multiple equivalences governed by ambivalences whose bases are held, as noted Arjun Appadurai (2001) in a negotiation between "the historical and the social, the affections and the politics, the global and the local".

This form of memory is convening what Mieke Bal (2001) calls "Preposterous History", which is like a "time shared" shortcut time. Memory, as pointed out by Mieke Bal, "is not able to transport its timeframe" (2009, p. 246). However, the relationship of images creates temporary networks that activate subjectivity and produce revision spaces of hegemonic and subordinate temporalities present in the collective imaginary. This temporal multiplicity develops various lines of action where the concept of time is between the heterochrony and the anachronism. Also Mark Godfrey (2007) has pointed out a historical procedure where certain sentimental, romantic and spectacular forms are due more to a critique of the representation of historical stereotypes, such as Hollywood, than to the exploration of suppressed stories anchored in the embezzlement of "the historical".

Amelia Barikin (2012) speaks about a "topological historicity" that reset temporary formats and introduces a "time released" and an "open present" where anything can happen at any time. To put it in words of Barikin (2012) memory incorporates duration that is developing throughout the difference, that is to say, that is delayed, expanding the time-event to reformulate and build the "fact" again. Barikin spoke in these terms about memory: "It is through montage, the way of mixing and linking images that we can create a representation of the fact which may be more accurate than the event itself" (2012, p. 12).

Didi-Huberman talks about the simple act of remembering, understood in the reconstructive sense, as itself an anachronistic act. The rescue of an image from memory or the evocations of a past is provoking confrontation with the present. In this way it is a fold in the timeline, a dimensional invasion arising from different times that come up involuntarily in the mind of the one who remembers, stripping the hieratic stiffness of the line and giving it a new flexible and dynamic corporeality. Didi-Huberman speaks well about the process of memory: “(...) Memory is psychic in its process, its effects anachronistic assembly, reconstruction, or "decantation" time. We cannot accept the commemorative dimension of history without accepting at the same time, its anchor in the unconscious and its anachronistic dimension" (2005, p. 40).

Daniel Birnbaum (2005) speaks about a "time delay" where there is a temporary form of consciousness that is close to what Freud called "delay action". This comes from the recombination of past and anticipated future in the subject, but 
also a function of a series of temporary differences. In this respect, Daniel Birnbaum (2005) suggests the time of the viewer and the time of the image literally as a resource to empty out the work of art and its symbolism, thus generating a new temporary chronology within the experimentation and the reception of the audio-visual works of art, that is to say, the own chronology of the viewer.

Peter Osborne (2010) proposed in his notions about "art and time" a new "cult of distraction" and a recovery of obsolete perception technologies to guarantee more opacity in the spectator reception, which aims to express modes of temporal experience and knowledge in the artwork. So the accessibility of the actual artwork involves the integration of subjectivity and the temporary suspension of the subject in this realization. The assumption of this framework rests on an understanding of contemporary art throughout an articulation of time and subjectivity, that is, throughout memory.

We then have these two concerns about the role of the spectator in the artwork reception. Both Birnbaum and Osborne notions are structured by mechanical temporary delay in the receptivity of the artwork. We then observe the temporal disparity as a symbolic stratification and the spatialization and the temporary bypass as guarantors of "the void of meaning" for the purpose of bringing out hidden meanings.

\section{Heterochronies and Anachronisms in "Inconsolable Memories"}

(...) The image is not in history as a point on a line. The image is not a single event in the historical development or an eternal extension insensitive to the conditions of that becoming. It has or rather it produces a double-sided temporality (...) Benjamin ended by grasping it in terms of "dialectics" and "dialectical image" (Didi-Huberman, 2008).

The concurrence of the memory images and the assumption of relations between time and image as a montage of heterogeneous and discontinuous times, that connect themselves in order to remove the chronological linearity, give way to the "reinterpretation" and using of "recombinant" narrative structures. Similarly the question of visual technologies and obsolescence is an appeal to a very substantial temporal relationship. The obsolescence used by Douglas shows a clear concern about the temporary systems that reproduce "memory images".

Douglas seeks a new interpretation from the reprocessing of existing film and literary materials. The installation Inconsolable Memories (2005) (fig. 1) is a reinterpretation of the Cuban film Memorias del subdesarrollo by Tomas Gutiérrez Alea. The work speculates with the narrative and history, and its contents have been reprocessed, although it retains elements of the original, incorporating narrative loops that articulate the experience of time and reorganize the events.

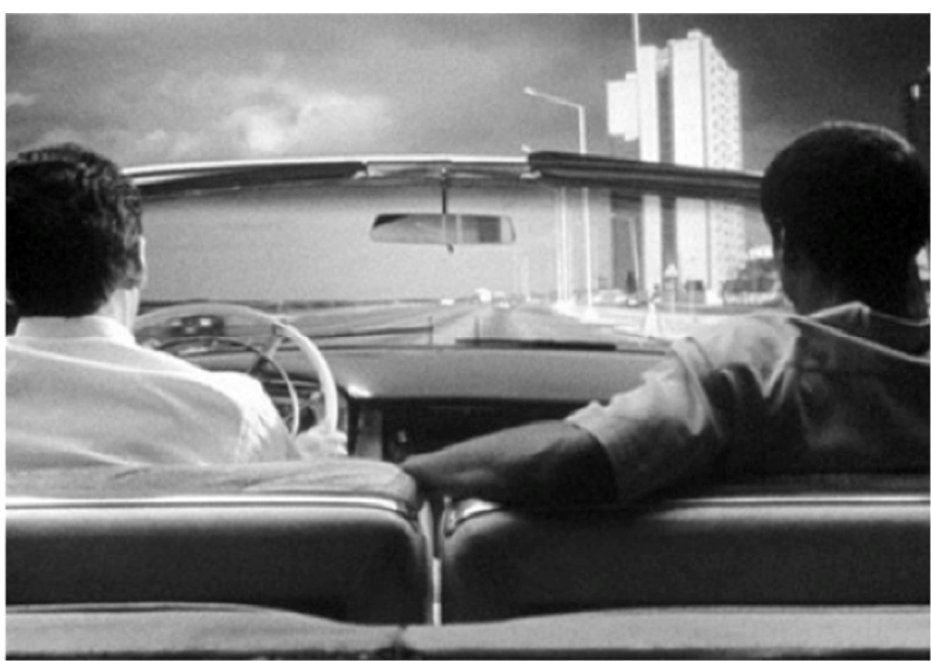

Figure 1. Stan Douglas, Inconsolable Memories, 2005. Source: http://hammer.ucla.edu/

Douglas manipulates the original film of Gutiérrez Alea changing the characters and introducing them to a divergent historical context in order to approach the problem of memory, history and identity. This approach is made by a combination of fact and fiction narratives. The recombination (the scenes are recombined each time the film is repeated) produces a spatialization of the temporal structure of the film. Douglas absorbs the viewer into twists and memory displacements recovered from the original film. He somehow confronts a combination of documentary reality and film portrait in which develops a poignant analysis of these elements.

By reinterpreting the history of Sergio two decades later, Douglas maintains the existential agony of the character and makes evident the contradictions of the Cuban revolution thereby representing a timeless structure that keeps the ideological failure and the original conflicts intact twenty years later. We could even say the incorporation of a perpetual present and the rhetoric of memory in the construction of the "national memory". 
Douglas made Inconsolable Memories (2005) with two 16-mm films in two channels with an installation that requires a circular movement. The piece reproduces fifteen permutations five minutes, thirty-nine seconds each, projected simultaneously on the same screen. There is an alternation in the projection, so that when one projector makes images, the other ones remain dark. The two loops are simultaneously projected with the uneven chronological configuration of films. Thus, mixing random images and sounds that reconfigure the narrative produces combinations and permutations. This produces a constant change, which causes new variations and interpretations through flashbacks and other overlaps that place events from the past in the present and articulate the narrative from multiple perspectives.

With this procedural strategy, evidence of an unfinished revolution is shown in which temporal process focuses on a dialogue between past and present, thus provoking reflection on the revolutionary utopia and the immediate future. In this sense recombinant movies not only reproduce the past, but also establish a dialectics with the present. This dialectics develops a temporal inventory, a personal time in direct opposition to a historic time. It's what Ernst Van Alphen (2009) has called "New Historiography". This is the perceptual experimentation and qualitative difference that exists between historical time and personal time, understanding historical time as one that depicts monochronic and realistic elements, and personal time to be one that draws the time of the images.

However, in Inconsolable Memories (2005) a fusion of both elements is proposed, where the penetration of historical time is overexposed to a personal time that gives to the resultant image a very specific interpretative tension. This game of antagonisms recreates the heterochronic system as a contingent element, in which methods are formulated to articulate a double fixed-unfixed movement of temporality and narrative. This movement cannot be fixed because there is an excess of meaning that overflows, trapped in infinite variables. This is what Laclau (1996) in his concept of antagonism calls "discursive".

One of the characteristic issues in many of Stan Douglas' works is the concept of anachronism as a constellation of opposing elements in constant dialogue. Obsolete visual technologies are displaced from their stable environment in social history by a programmed capitalism, as too the spaces and places taken away from its planned functionalism by an expansion of different political, economic and social issues. The visual technologies show an unusual interest in rehabilitating a kind of objectual, spatial and temporal dialectics about the concept of obsolescence. Thus, temporal relations are established on the concept of obsolescence, since Douglas in his film combines interior design, objects or places situating them in previous decades. Also, he consciously introduces damaged visual technologies superimposing images to other functional ones. Using documentary materials filmed with obsolete technologies and especially the temporal span established between the deconstruction of literary and visual genres and their subsequent historiographical recombination incorporate a program of visual dialectic obsolescence.

This also occurs to the extent that it reprocesses patterns of race, sex and gender imposed by Hollywood cinema and commercial television, empowering the stereotypical colonial discourse. Here the recognition of difference and substitution of patterns makes an otherness that has maximum potential political irony causing a collision that transforms temporal narratives giving alternative ways of perception to his projects.

Also obsolete technologies are material artifacts of the past that can be recovered and used in the present in order to rethink the relationship between the various historical models of production and consumption that capitalism has built. Film techniques are closely related to the development of technology, economy and ideology. These technological developments that expand the ways to "make movies" are also embedded in an economic, ideological and political network, which at last defines its own way, its own existence and doing. Therefore, employing this technological anachronism in its symbolic form, Douglas work also establishes a dialectics with ideological past. Frederic Jameson (1999) has called this "planned obsolescence".

The Messianic dialectic of Benjamin, as interpreted by José Zamora (2008), displays a relationship between the past and the present. Here the ruins, debris, buried and forgotten remnants emerge in a kind of instantaneous that stops time. This kind of time with a clear political, ideological viewpoint legitimates the linear temporality of the dominant hegemonic narratives that have fossilized any dialectic, but at the same time have enabled a regime of temporal visibility. Here the memory is organized with materialistic parameters and the object and the fragment determine the totality, the truth. That is, the disruption of historical temporality and the stopping of time occur through the material remains that suspend the present and create a dialogue with the past. Here the otherness creates conditions of possibility.

Following this debate about the anachronism in the work of Stan Douglas, we have to mention the implicit relationship between the old and the new. Extending the life of obsolete machines is to question our obsession with the new. It is an impulse to use the old systems to distance itself from a consumer culture and open this critical debate.

In this regard, it would be interesting to bring in here the reflection of Miguel Ángel Hernández Navarro (2010) on the writings of Walter Benjamin about obsolescence and ruin, where 
The obsolete, the outmoded, outdated is not dead, but is latent. The obsolete object has been put aside of time. According to Benjamin's notes it is at that moment when the object has been expelled from the regime of novelty, when the object is no longer modern, when the different layers of meaning that are concentrated in it are revealed. The obsolete object, then shows the catastrophe that lies behind the dream world. The object becomes a dialectical image when viewed (when think) these opposing forces, when is seen that after the new is the old, that after the continuous progress is being-always-in-the-same-site, that after the appearance of freedom is at the end in the chain, which, ultimately, after the promised happiness is the reality of dissatisfaction (2010, p. 15).

Indeed, this strategy of temporal shifts and symbolic recombinations embrace new meanings to the artwork by means of the transgressions that reconfigure the historicity of forms. Hernández-Navarro (2012) has called this "strategic fetishism", claiming objectual, historical and contingent materiality as guarantor of a political revival of memory discourses, discarding the commodified counterweight of the discourses of nostalgia.

\section{Narrative Temporality in "Interiors"}

Almost all productions of Doug Aitken rest on a constant hybridization of amplified and fragmented narratives, existing with reversible and simultaneous times. In his work a variety of spatial-temporal consciousness is running in unison. Perhaps a good graphical idea to understand time in his works is the dissection of a polyhedron and its articulation in space. We find discontinuous narratives that juxtapose interconnected palimpsests. Here, the story is suspended in a constant anachronism that the viewer must solve, articulating various planes-screen in a plural heterochronic understanding of events, thus building his personal story, his personal time, that of the viewer.

Therefore, in Aitken's work, narrative discontinuity and hybridization temporalities are articulated by the apprehension of the global work. The specific, the local, the ephemeral is related to the global in an intuitive and deductive process where everything is in constant motion. Perhaps Aitken, better than anyone else, articulates "Benjamin's fleeting moment". This temporal "instant" that allows the particular and the general, the concrete and the abstract, to articulate discontinuous and intermittently.

In this sense a work such as Interiors (2002) (fig. 2) is articulated. It is an architectural installation combining three projections on translucent screens, lasting six minutes and fifty-five seconds each loop. The installation is conceived as an architectural structure composed of eleven translucent screens forming a cross. In the center lie circular seats that allow Panoptic view of the entire installation. At the ends of three of the rooms created by the screens of this visual surrounding architecture, images synchronized with the soundtrack appear. These projections are articulated in a dizzying choreography where the frantic ecstasy between the visual and the sound causes discontinuous and fragmentary narrative moments. Apparently these have no connection between them. However, in this flow of images and sound the screens appear to be connected to each other and begin to articulate an interpretive register. That's all and everything starts again.

The architectural structure that forms Interiors (2002) is transparent. From both the inside and the outside of the installation, everything is visible. Also running projections on the ends of three transparent screens and images can be seen on both sides, from inside and outside, by the viewer. And, from certain locations of the installation, we can observe a displacement inside and outside under visual reflection due to the formation of planes that form a cross, open on one side. Optical aberrations produce times of lighter reception or more intense perception as a result of the loss of sharpness caused by the layered view between transparent panels.

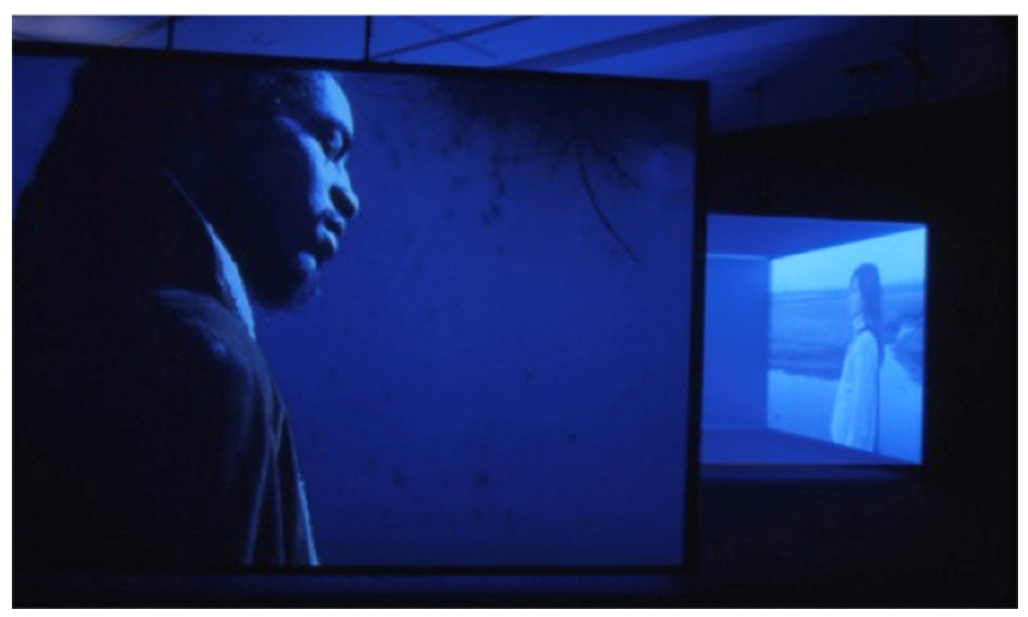

Figure 2. Doug Aitken, Interiors, 2002. Source: http://momaps1.org 
Thus, the images show representations of characters doing everyday actions in an accumulation of moments that bear no relation between them. The relationship is established by compositional similarities and intensification of rhythms. They appear to be repetitive elements, combining with no narrative tie at all, but trapped in a regressive form, mesmerizing the viewer. This causes some activation of collective memory. One has the suspicion that the permanent memory record incorporated in the work of Aitken, as mentioned by Andreas Huyssen (2002) is due to an appropriation of the past, developing consistent strategies to rebuild the social and collective identity, in the form of spectacle.

Furthermore, the juxtaposition of images and acceleration demands a recalibration of perception, which clearly breaks the linear narrative, the central time and the "grand narrative". Sometimes, contemplating the works of Aitken, one has the feeling of traveling in constant movement, with a fragmentary imaginary apprehension. So, "the dragging" of movement and the constant appearance of new landscapes merging with that which is fleeting from our retina generate an experiential anachronism that disables any attempt at logic.

Similarly, the reception temporalities of Interiors (2002) are multiple and contradictory. Peter Osborne (2010) proposes a dialectics of duration as an element that brings together the absorption and indifference of the viewer in the reception of the artwork. In the "meantime" is where Aitken made the latest expansion of its temporalities and the confluence of narratives. Since he articulates the instantaneous, the momentary and temporary reverberation that allows the viewer to construct an image more, within the installation. Raymond Bellour (2009) identifies the wandering spectator of art installations as follows: "The viewer of the installation is a walker, is so sensitive to the passage between the images that his own body, sometimes goes with the image, and he himself is running through images" (2009, p. 16).

What we want to say is that in Interiors (2002) the viewer in his wanderings through the installation, linked to the transparent architectural structure, becomes part of it as an image, a projection. Within the logic of the moment a depletion of the exterior-interior in the work is taking place, in which "we perceive that we are being perceived" as expressed by Friedrich W. Heubach (Graham, 1997) about the work of Dan Graham. So we have to agree that the time of images in Interiors (2002) claims a kind of hybridization experience of "fleeting moments" in order to articulate "other different times".

\section{Anachronism and Spatiality in "North Circular"}

The localization process is inherent to the medium of film and Mark Lewis dialectic and analytically reconfigures this process placing a modern architecture building in ruins as the main actor of the movie. Lewis uses locations indicating some idea about the spatial and temporal architectural utopia of modernity of the late $60 \mathrm{~s}$ and he uses it anachronistically. The criticism of architectural utopia of modernity as contextual space is a characteristic of Lewis' work. Modernity trying to embody social structures and ideals in a body of material designed to live and to be experienced. Lewis incorporates the failure and obsolescence of the utopian project in his work.

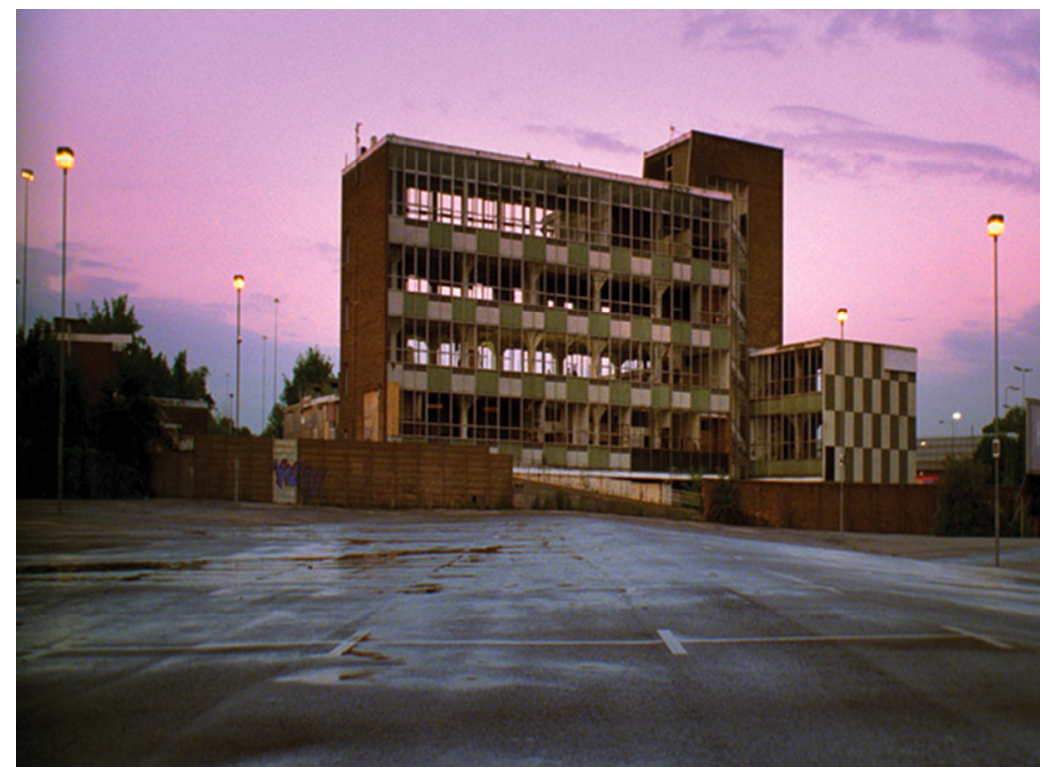

Figure 3. Mark Lewis, North Circular, 2000. Source: http://www.ago.net/

The scene of "North Circular" is composed of a long shot using a crane located in an empty parking lot. From a distance, only an almost imperceptible movement of life is seen in a desolate space through the broken windows of a modern building in ruins. The work begins with a photographic stasis. Lewis suggests in his pieces a calculated ambiguity 
between the immobility of photography and the succession of images that evoke movement (Ross, 2012, p. 59). Lewis plays with the temporality of the sequence in a slow tracking shot that reveals the obsolescence of place and uses the kinematic sequence shot in order to emerge the visual anachronism as a narrative device. As Didi-Huberman asserts "before the image we are always before the time" and before the time we have always the anachronistic and polytemporal look that is what enables the complexity and exuberance of images and the archaeological time of the represented space.

In North Circular (2000) (fig. 3) Lewis compares the "non-place" (1995) of an unoccupied parking lot with the deserted office structure, creating a reenactment of the "anthropological place" through the presence of three children inside the office structure. The "non place" is represented by the abandoned building on the outskirts of "North Circular", in which its meaning interrupts and reenacts its life from a nested narrative construction that is temporary and spatially opposed to the current reading of space and building. The abandoned building represents the atomization location and the lack of socialization of place. It represents the displacement of exchange and is established as the center of nowhere, where anybody lives.

Lewis' work is based on the critical review of the Plan Voisin Le Corbusier 1925 in which it was proposed to replace the historic sites of the city, with modern towers as living machines, regardless of attention and perception of specific location (Ross, 2012, p. 120-125). In so doing, Lewis relocates his filmic narratives in the reducing abstraction of the history and humanism of the modern architecture that Anthony Vindler has called "the vocabulary of isolation and sterility" (Ross, 2012, p. 123). The modern project as historical reflection and postmodernism recovery as Vindler points out, is not only a rejection of all modern things, but an invitation to rethink the time and space we inhabit, and understand the strengths and disconnections that are articulated in the urban and experiential field. In this way Lewis' work reflects, not a rejection of modernity, but a display of their sutures, its union and disunity between the bodies and the spatial and temporal symbols.

In North Circular Lewis makes a double gesture based on invisibility and presence, and redirects a vulgar scene of everyday routine, from inattention to the perceptual focus and attention to the object and the subject of the game, leaving the industrial building in ruins almost out of visual control. At the same time the building is diluted in its initial phase to become after framework of the main subject: the game of spinning tops. Lewis incorporates another visual anachronism this time coming from art history in order to give meaning to their temporal scenarios, a painting by Jean-Baptiste Chardin "L'enfant au toton" (1738) from which he reproduces the game of kids in the scene.

\section{Conclusions}

A whole system of overlapped temporalities and memories activate a system of opposites in the works of these authors that dialogue between: remembering and forgetting, attention-distraction, organization and recontextualization of the territory, the selection and exclusion of historical memory and the presentation and interpretation of collective memory.

These variables are undertaken from a temporal analysis of their work that unfold positions that make a revision of what Koselleck (2001) called "temporal layers and strata" present in them. Thus, the interplay and fusion of narrative representations involved in trying to discern in such complex works, the connections between past, present and future. This is done through the articulation, recombination and juxtaposition of temporary architectures that obey a fusion and deconstruction of ideological and cultural discourses, but ultimately, deepen and reveal the constitution of social subjects immersed in these processes. And ultimately, the use of the polytemporalities, the anachronism as a form of expression, reflecting the debate on the temporalities studies especially in the contemporary artistic production. In fact, this debate follows the definition of Boris Groys about the contemporary as a "prolonged even potentially infinite period of delay" (2009). This can explain in the way that we can only understand the contemporary from the reconstruction of the past, that is to say from memory.

The whole study has been considered regarding visual culture where theories of "antagonist capitalism" (Brea, 2010) and the integration of discourses of heterocronic resistance to linear and monochronic time of modernity are framed. Also, the crisis of the storytelling and the temporal reception in these works has been developed through a theory of reception. Where on the one hand, a temporality of consumption corresponding to an inactive spectator is analyzed, and on the other, a timing of experience corresponding to an active viewer that displays a dialectic of duration as an element that brings the absorption and indifference is proposed in the reception of the artwork.

\section{Acknowledgements}

This work is included in the whole of the research proposed by the research project: 'Temporal image: heterochrony and anachronism in contemporary visual culture', HAR-ref. 2012-39322. The paper is funded under the program of the 'Dirección General de Investigación y Gestión del Plan Nacional I+D+I de Proyectos de Investigación del Ministerio de Economía y Competitividad' of the Government of Spain. 


\section{References}

Appadurai, A. (2001). La modernidad desbordada. Dimensiones culturales de la globalización. Montevideo: Ediciones Trilice y Fondo de Cultura Económica.

Augé, M. (1995). Non-Places: Introduction to an Anthropology of Supermodernity. London: Verso.

Bal, M. (2001). Quoting Caravaggio. Contemporary Art, Preposterous History. Chicago: Chicago University Press.

Bal, M. (2009). Conceptos viajeros en las humanidades. Una guía de viaje. Murcia: Cendeac.

Barikin, A. (2012). Parallel Presents: The Art of Pierre Huyghe. Cambridge, Mass.: MIT Press.

Bellour, R. (2009). Entre imágenes: foto, cine, vídeo. Buenos Aires: Colihue.

Birnbaum, D. (2005). Chronology. New York: Lukas \& Sternberg.

Brea, J. L. (2010). Retóricas de la resistencia: una introducción.Estudios Visuales, 7, 8-13.

Buck-Morss, S. (2005). Walter Benjamin, escritor revolucionario. Buenos Aires: Interzona Editora.

Damisch, H. (1995). El juicio de Paris. México: Ed. S. XXI.

Didi-Huberman, G. (2005). Imágenes pese a todo. Memoria visual del Holocausto. Barcelona: Paidós.

Didi-Huberman, G. (2008). Ante el tiempo. Historia del arte y anacronismo de las imágenes. Buenos Aires: Adriana Hidalgo.

Godfrey, M. (2007). The Artist as Historian. 120, spring, 140-172. http://dx.doi.org/10.1162/octo.2007.120.1.140

Graham, D. et al. (1997). Dan Graham. Santiago de Compostela: Centro Galego de Arte Contemporánea.

Groys, B. (2009). Comrades of Time. e-flux journal, 11. http://www.e-flux.com/journal/comrades-of-time/

Guasch, A. M. (2011). Arte y Archivo, 1920-2010. Genealogías, Tipologías y Discontinuidades. Madrid: Ed. Akal.

Hernández-Navarro, M. Á. (2011). "Hacer visible el pasado. El artista como historiador (benjaminiano)”. In De la Villa Ardura, R. ed. Sociedades en crisis: Europa y el concepto de estética, pp. 238-249. Madrid: Ministerio de Cultura.

Hernández-Navarro, M. Á. (2012). Materializar el pasado. El artista como historiador (benjaminiano). Murcia: Ed. Micromegas.

Huyssen, A. (2002). En busca del futuro perdido. Cultura y memoria en tiempos de globalización. México: Fondo de Cultura Económica.

Jameson, F. (1999). El giro cultural. Escritos seleccionados sobre el posmodernismo 1983-1998. Buenos Aires: Ed. Manantial.

Koselleck, R. (2001). Los estratos del tiempo: estudios sobre historia. Barcelona: Paidós.

Laclau, E. (1996). Emancipación y diferencia. Buenos Aires: Ariel.

Osborne, P. (2010). El arte más allá de la estética. Ensayos filosóficos sobre arte contemporáneo. Murcia: Cendeac.

Ricoeur, P. (1999). La lectura del tiempo pasado: memoria y olvido. Madrid: Editorial Arrecife.

Ross, C. (2012). The Past is the Present, It's the Future Too: The Temporal Turn in Contemporary Art. London: Bloomsbury Publishing.

Van Alphen, E. (2009). Hacia una nueva historiografía: Peter Fogács y la estética de la temporalidad. Estudios visuales, 6, 30-47.

Zamora, J. A. (2008). Dialéctica mesiánica: tiempo e interrupción en Walter Benjamin. In Amengual, G. y Cabot, M. (coords). Ruptura de la tradición: estudios sobre Walter Benjamin y Martin Heidegger, 83-138. Madrid: Trotta.

\section{(cc) BY}

This work is licensed under a Creative Commons Attribution 3.0 License. 